\title{
Evidence for decrease in size of lesser sandeels Ammodytes marinus in a North Sea aggregation over a 30-yr period
}

\author{
S. Wanless ${ }^{1, *}$, P. J. Wright ${ }^{2}$, M. P. Harris ${ }^{1}$, D. A. Elston ${ }^{3}$ \\ ${ }^{1}$ Natural Environment Research Council (NERC), Centre for Ecology and Hydrology, Hill of Brathens, Banchory AB31 4BW, UK \\ ${ }^{2}$ Fisheries Research Services Marine Laboratory, PO Box 101, 375 Victoria Road, Torry, Aberdeen AB11 9DB, UK \\ ${ }^{3}$ Biomathematics \& Statistics Scotland, The Macaulay Institute, Craigiebuckler, Aberdeen AB15 8QH, UK
}

\begin{abstract}
Long-term changes in size of the lesser sandeels Ammodytes marinus in the Wee Bankie aggregation in the northwest part of the North Sea were investigated using individuals collected from Atlantic puffins Fratercula arctica feeding chicks. Between 1973 and 2002, the average size, on a given date, of fish hatched that year (0-group) declined by $11.1 \mathrm{~mm}$. Over the same period, older (predominantly 1-group) sandeels showed an overall reduction in size on a given date, of $19.4 \mathrm{~mm}$ fish $^{-1}$. In both cases the change in length corresponded to a $40 \%$ decline in energy content. These long-term trends in size-at-age are likely to have had major demographic consequences for this aggregation in terms of delayed sexual maturity and lower age-specific fecundity. While there was no evidence that the decrease was associated with the start of an industrial sandeel fishery in the area in 1990, the observed decline in size-at-age could potentially make this aggregation more vulnerable to collapse because of its reduced capacity to produce eggs. We tentatively suggest that changing environmental conditions from the early 1980s onwards, acting through effects on early growth and/or hatch date, may have contributed to the long-term decline in size of 0-group sandeels in this area. More data are needed to elucidate the reasons for the decline in the size of older sandeels.
\end{abstract}

KEY WORDS: Climate change $\cdot$ Environmental monitoring $\cdot$ North Sea $\cdot$ Industrial fishery $\cdot$ Larval growth rate Atlantic puffin

Resale or republication not permitted without written consent of the publisher

\section{INTRODUCTION}

The lesser sandeel Ammodytes marinus is an important component of the North Sea food web, forming a crucial mid-trophic link between zooplankton production and top predators such as fishes, seabirds and marine mammals (Harwood \& Croxall 1988, Greenstreet 1996, Furness \& Tasker 2000). It is also the target of the largest commercial fishery in the area, with annual catches ranging from 0.54 to 1.1 million tonnes between 1982 and 2001 (ICES 2003). Assessments of sandeel stocks at a North Sea scale have been made since 1983, but there is now evidence that there are several distinct aggregations of sandeels with limited movement between them (Proctor et al. 1998, Pedersen et al. 1999, Munk et al. 2002). One such aggregation off the northeast coast of mainland Britain has been the target of an industrial fishery on the Wee Bankie, Marr Bank and associated banks off the entrance to the Firth of Forth, SE Scotland (Fig. 1). The fishery started in 1990, with landings quickly reaching a peak of over 100000 t in 1993 (Rindorf et al. 2000). Relatively little is known of the dynamics of this aggregation but, due to concern about the possible impact the fishery was having on local predators, particularly breeding seabirds that depend heavily on this species (Hamer et al. 2000, Rindorf et al. 2000), the fishery was closed in 2000 and remains closed up to the present (2004).

Changes within sandeel stocks are heavily dependent on year-class strength, particularly in exploited 
stocks, where fish under $3 \mathrm{yr}$ old predominate (Wright 1996, ICES 2003). Lesser sandeels lay demersal eggs between December and January and the larvae hatch from February to April (Winslade 1971, Wright \& Bailey 1996). The larvae are planktonic for between 1 and $3 \mathrm{mo}$, after which they develop a silvery underside and adopt the burying habit of adults. Their early growth appears dependent on the degree of synchrony between hatch times and the onset of the secondary spring production of zooplankton (Wright \& Bailey 1996). Due to inter-annual differences in hatch time and early growth rate, size prior to and shortly after settlement can vary considerably (Wright \& Bailey 1996).

Until the recent concerns over the impact of the fishery prompted investigation, little was known about the sandeels off the Firth of Forth (for convenience termed here 'the Wee Bankie' after the main fishing area). A recent study that compared life-history characteristics of sandeels among different fished aggregations throughout the North Sea found that those at the Wee Bankie, like those from Shetland and Norway, were relatively slow-growing, and were around half the mean weight-at-age in North Sea assessments (Wright \& Bailey 1996, Bergstad et al. 2002, ICES 2003, P. J. Wright unpubl. data). These relatively slow-growing sandeels tend to mature at an older age and smaller size than those from aggregations in the central North Sea (Wright \& Bailey 1996, Bergstad et al. 2002), thus making them more vulnerable to overfishing.

A major factor hampering detailed investigation of the reasons for these inter-aggregation differences is the lack of long-term fisheries data for sandeels at a local scale. Such data are, however, available for the Wee Bankie aggregation from long-term studies of seabirds on the Isle of May in the entrance to the Firth of Forth (Fig. 1), where sandeels are an important component of the diet of many of the species during the breeding season (Harris \& Hislop 1978, Harris \&

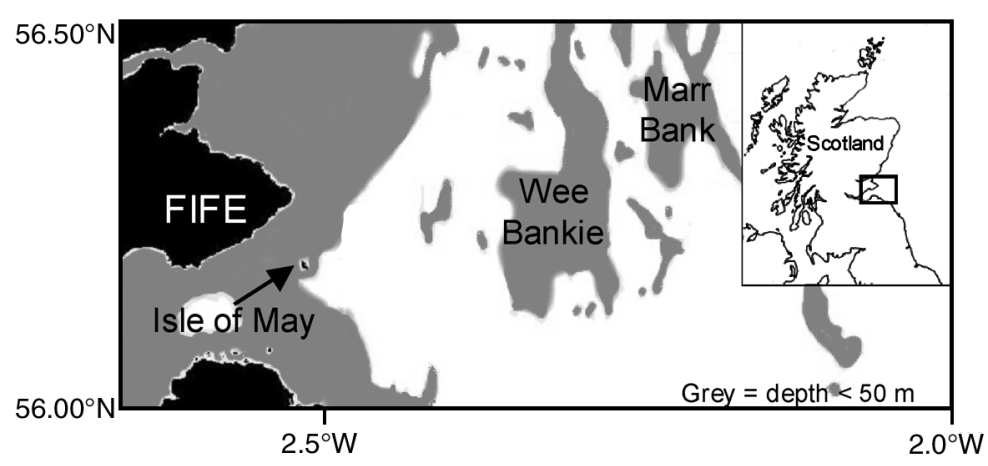

Fig. 1. Study area showing location of Isle of May where lesser sandeels Ammodytes marinus were collected from Atlantic puffins Fratercula arctica. Also shown are Wee Bankie and Marr Bank, where industrial fishery previously operated
Wanless 1986, 1991, Lewis et al. 2001). Here we present data collected from the Atlantic puffin Fratercula arctica. This data set is well-suited for assessing long term changes in sandeel size because (1) it covers a period of $30 \mathrm{yr}$, (2) the annual sampling period between late May and late July is appropriate for assessing sandeel size, (3) sandeels are an important component of the puffin's diet (Harris \& Hislop 1978, Hislop \& Harris 1985) and sample sizes, particularly of 0-group fish, are large, (4) puffins bring back intact fish that are easily and accurately measured, (5) puffins typically feed within about $30 \mathrm{~km}$ of the Isle of May (Harris 1984), and thus most, probably all, sandeels will have come from the Wee Bankie aggregation; and (6) puffins are pursuit-divers, with a maximum depth of $70 \mathrm{~m}$ (Burger \& Simpson 1986) that is considerably deeper than the sea in the study area, thus enabling birds to catch sandeels throughout the water column. After initially establishing that there is close agreement in the size distributions of samples collected concurrently from fisheries surveys and puffins, we present an analysis of the time-series data from puffins to look for long-term changes in sandeel size and summer growth rates and discuss whether there is evidence that changes were associated with environmental factors and/or changes in fishing pressure on the Wee Bankie.

\section{MATERIALS AND METHODS}

Sampling sandeels. Samples of lesser sandeels were obtained by flight-netting puffins returning to the breeding colony on the Isle of May on between 5 and $24 \mathrm{~d}$ in every year (except 1980) between 1973 and 2002. Dropped fish were collected and the total length of each sandeel was measured to the nearest $\mathrm{mm}$ from the tip of the snout to the end of the tail. Details of the number and spread of sampling dates and the numbers of sandeels measured are given in Table 1.

Sandeels spend much of the year buried in the sand, and the duration and timing of the period spent in the water column varies with fish age (Reay 1970, Wright \& Bailey 1993). Our sampling period was dictated by the chick-rearing period of the puffins, since this is the only time birds return to land with fishes. Throughout the study, this period was between late May and the end of July. This was ideal for sampling 0-group sandeels, since individuals of this age are present in the water column throughout this time. However, it was less ideal for older age groups, since the latter part coincided with the period when the fish 
Table 1. Ammodytes marinus. Details of sampling of lesser sandeels collected from Atlantic puffins Fratercula arctica on Isle of May 1973-2002

\begin{tabular}{|c|c|c|c|c|c|}
\hline Year & $\begin{array}{l}\text { First } \\
\text { date }\end{array}$ & $\begin{array}{l}\text { Last } \\
\text { date }\end{array}$ & $\begin{array}{c}\text { Days } \\
\text { sampled }\end{array}$ & $\begin{array}{l}0 \text {-group } \\
\text { measured }\end{array}$ & $\begin{array}{l}\text { Older fish } \\
\text { measured }\end{array}$ \\
\hline 1973 & 13 June & 19 July & 12 & 321 & 3 \\
\hline 1974 & 3 June & 25 July & 24 & 386 & 24 \\
\hline 1975 & 9 June & 17 July & 5 & 79 & 13 \\
\hline 1976 & 3 June & 30 July & 19 & 390 & 6 \\
\hline 1977 & 16 June & 31 July & 23 & 273 & 18 \\
\hline 1978 & 5 June & 26 July & 20 & 256 & 22 \\
\hline 1979 & 24 June & 31July & 20 & 211 & 85 \\
\hline 1981 & 24 June & 31 July & 24 & 254 & 38 \\
\hline 1982 & 2 June & 31 July & 8 & 109 & 80 \\
\hline 1983 & 2 June & 30 July & 16 & 417 & 102 \\
\hline 1984 & 7 June & 29 July & 18 & 370 & 136 \\
\hline 1985 & 27 May & 5 July & 6 & 804 & 110 \\
\hline 1986 & 7 June & 15 July & 8 & 155 & 86 \\
\hline 1987 & 16 June & 13 July & 8 & 164 & 131 \\
\hline 1988 & 14 June & 4 July & 9 & 709 & 32 \\
\hline 1989 & 14 June & 10 July & 14 & 568 & 3 \\
\hline 1990 & 8 June & 7 July & 13 & 450 & 14 \\
\hline 1991 & 6 June & 7 July & 14 & 782 & 72 \\
\hline 1992 & 3 June & 15 July & 7 & 599 & 70 \\
\hline 1993 & 9 June & 12 July & 13 & 728 & 54 \\
\hline 1994 & 19 June & 13 July & 11 & 756 & 45 \\
\hline 1995 & 18 June & 13 July & 9 & 344 & 69 \\
\hline 1996 & 14 June & 16 July & 9 & 852 & 27 \\
\hline 1997 & 3 June & 8 July & 13 & 639 & 25 \\
\hline 1998 & 13 June & 31 July & 20 & 2871 & 77 \\
\hline 1999 & 31 May & 10 July & 16 & 1441 & 32 \\
\hline 2000 & 29 May & 13 July & 19 & 1732 & 81 \\
\hline 2001 & 2 June & 14 July & 10 & 1852 & 80 \\
\hline 2002 & 26 May & 16 July & 14 & 1592 & 103 \\
\hline
\end{tabular}

are starting to go back into the sand (Reeves 1994, Pedersen et al. 1999) and thus becoming increasingly unavailable to puffins.

Analysis of data. Visual inspection of scatter-plots of fish length against sampling date revealed a very consistent pattern, such that within each year there was a clear division into 2 length classes (Fig. 2). The simplest explanation for this was that the smaller fish on a given day were 0-group while larger fish were older. The validity of this was checked in 2000, 2001 and 2002 by removing otoliths from fish after they had been measured and determining fish age from otolith macrostructure. Otoliths were read whole in water against a black background using reflected light. Interpretation of the counts of annuli followed guidelines given in ICES (1995). For each of the 3 yr we plotted the length-frequency distributions for each sampling date. Discriminant analysis was then used to separate small (assumed to be 0-group fish) from larger (older) sandeels. This technique correctly identified the ages of 4161 (99.8\%) of the 4169 otoliths. We therefore used this method to classify sandeels as either 0-group or older for earlier years. While the majority of the larger-size fish appeared to be 1-group it proved impossible to separate further between older year-classes due to small samples and size overlap between year-classes.

Plots of intra-annual changes in length of 0-group fish for each year of the study are shown in Fig. 3. Lengths of 0-group sandeels were analysed statistically by fitting linear mixed models using the method of residual maximum likelihood (REML, Patterson \& Thompson 1971) as implemented in GenStat for Windows (GenStatCommittee 2002). The models fitted included covariates for day number within calendar year (hereafter referred to, for convenience, as Julian day $x \_$day) and calendar year ( $x$ _year) as fixedeffects, and categorical variables for sampling day (c_day) and calendar year (c_year) as random-effects to allow the standard errors for the covariates to be calculated using appropriate sources of random variation. Initial attempts to obtain year-specific regressions on Julian day involved treating these as fixedeffects. However, as some years had few samples, this led to negative estimates of growth rate for some years. More plausible estimates were obtained by treating the interaction between $x_{\text {_day }}$ and $c_{-}$year as random, since the slopes for years with little information were then shrunk towards the estimated mean slope for all years. The interaction between $x \_$day and $x_{-}$year was far from being statistically significant, and this term was therefore excluded from the final model. The equation of this model for the length $(\mathrm{mm}), y_{i j k}$, of the $k$ th fish caught on the $j$ th day, $x_{-}$day $_{i j}$, of the ith year, $x_{-}$year $_{i}$, with both covariates and all random effects, was:

$$
y_{i j k}=\alpha+\beta_{1} \times x_{-} \text {year }_{i}+\beta_{2 i} \times x_{-} \text {day }_{i j}+e_{i}+f_{i j}+g_{i j k}
$$

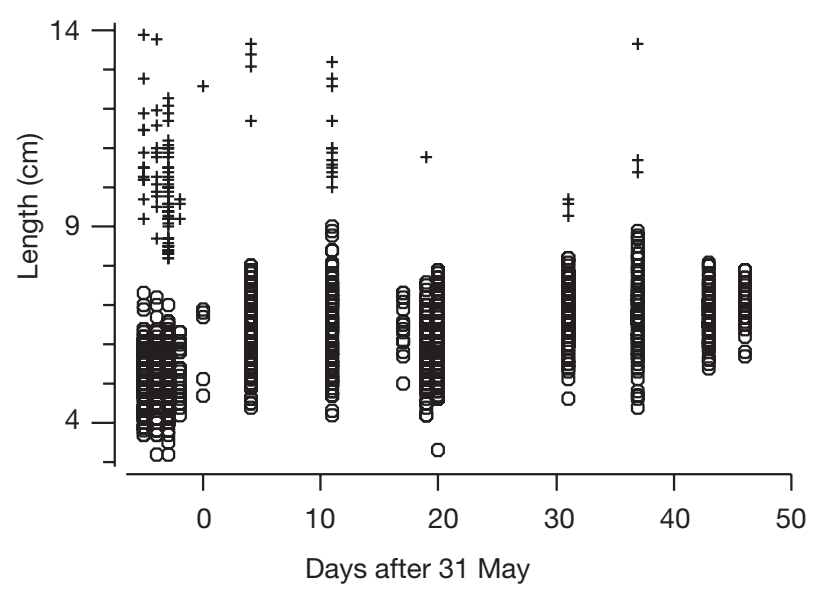

Fig. 2. Ammodytes marinus. Lengths of 15920 -group (o) and 103 older (+) lesser sandeels collected from Atlantic puffins Fratercula arctica on Isle of May on 14 dates between 26 May and 16 July 2002. Fish were aged by examination of otolith macrostructure 

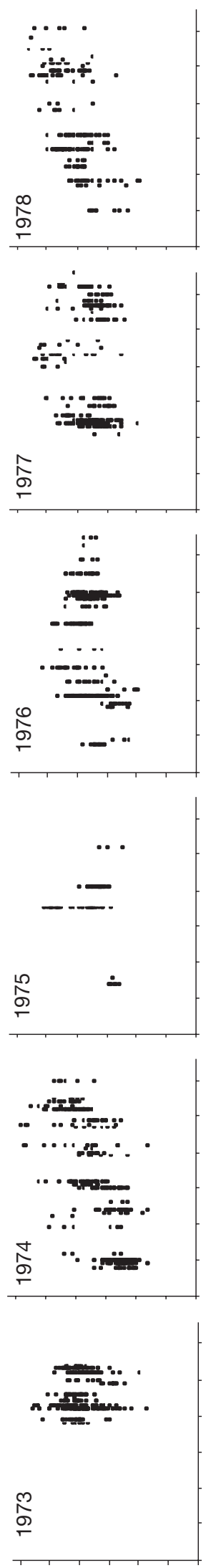

오응ㅇㅇㅇㅇㅇㅇㅇ Length (mm)
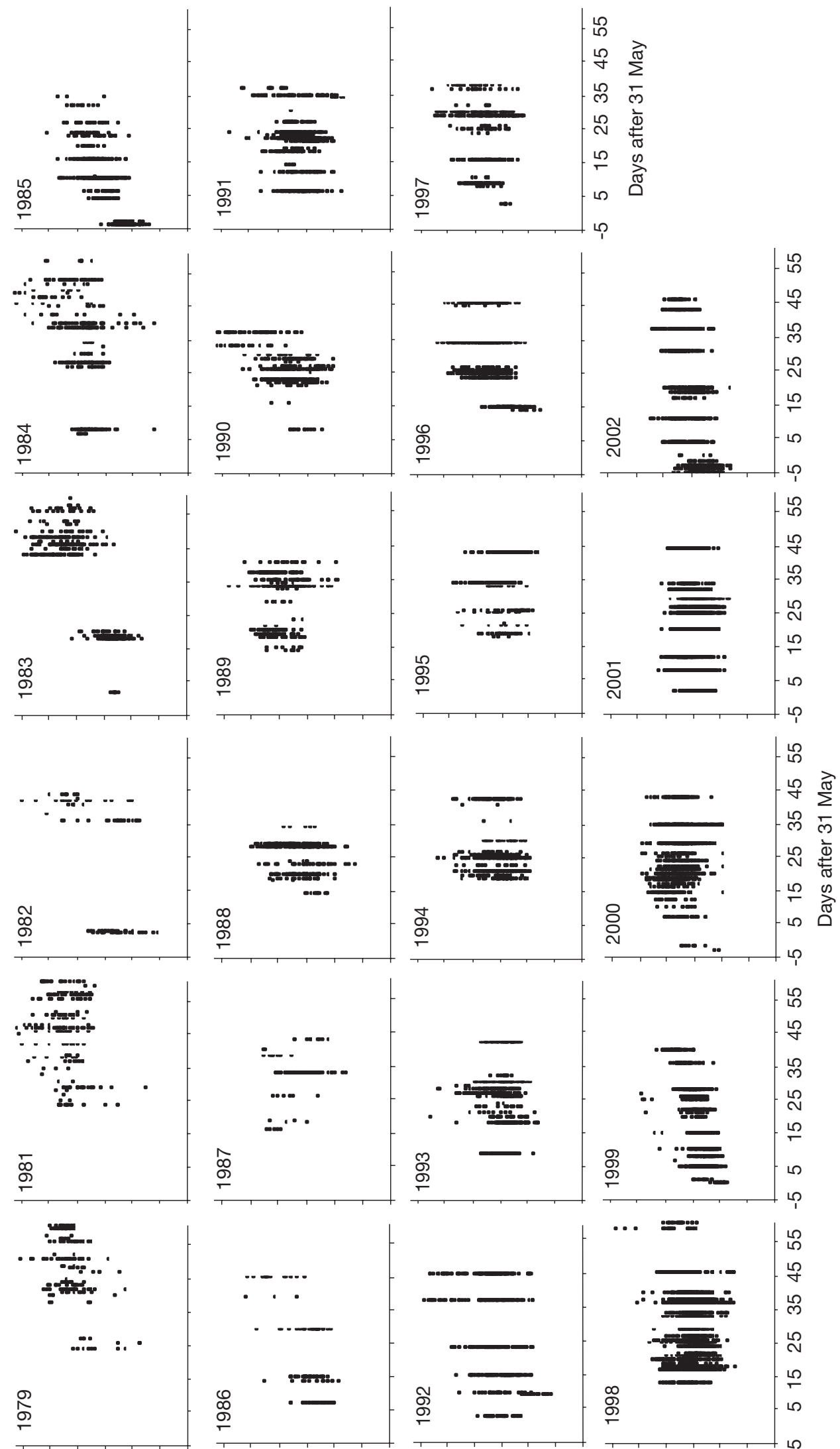

88808800 Length $(\mathrm{mm})$

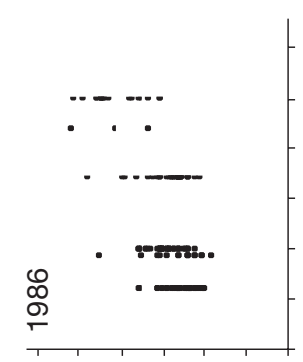

응ㅇㅇㅇㅇㅇㅇ Length $(\mathrm{mm})$

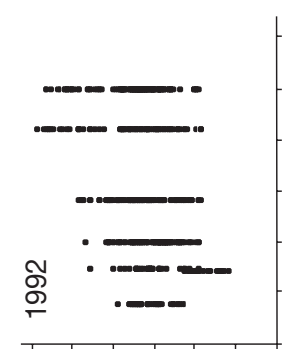

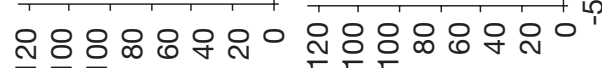
Length $(\mathrm{mm}) \quad$ Length $(\mathrm{mm})$ 
where the year-specific random regression coefficient, $\beta_{2 i}$, was assumed to follow a normal distribution with mean $\beta_{2}$ and variance $\sigma_{\beta_{2}}^{2}$ [i.e. $\beta_{2 i} \sim N\left(\beta_{2}, \sigma_{\beta_{2}}^{2}\right)$ and the additive year $\left(e_{i}\right)$, day $\left(f_{i j}\right)$ and residual $\left(g_{i j k}\right)$ terms were assumed to follow normal distributions with means all zero and variances $\sigma_{e}^{2}, \sigma_{f}^{2}$ and $\sigma_{g}^{2}$ respectively. All random-effects were considered independent, with the exception of the year-specific terms $\beta_{2 i}$ and $e_{i r}$ whose correlation was considered as an additional parameter in the random-effect model, thereby ensuring that the results were insensitive to the choice of Julian day for use as zero in $x_{-}$day. The above model was used to obtain annual estimates of the length of an individual sandeel standardised to 1 July (a date within the sampling period in every yr).

The above model assumes that both length-at-date and intra-annual growth rate change linearly over years. This assumption would be violated if abrupt changes in conditions for sandeels occurred during the study period. Whilst we have no information on the potential causes of change, the establishment of a sandeel fishery in 1990 led us to consider whether any growth change occurred prior to or following the onset of this fishery. The types of departure from the model that we considered were, firstly, a step change by a constant amount for the duration of the cause; secondly, a change of magnitude incrementing linearly from the hypothetical change point. The incremental change was implemented by fitting a broken-stick model, with the term for onset of the fishery being added after allowing for a potential break of slope subsequent to the fishery.

These analyses were repeated for older sandeels to obtain annual estimates of the length of an individual sandeel standardised to 1 June, rather than 1 July, since the bulk of older fish came from early in the season (Fig. 2). As mentioned earlier, our sample of older sandeels was potentially composed of several age classes and our sampling period also coincided with the time when older sandeels were starting to bury in the sand and thus becoming unavailable to puffins. We were therefore more cautious about how we used these data, and so for the older sandeels we did not estimate annual growth rates or carry out formal analyses to test for fishery or environmental effects.

Annual estimates of the energy value (EV) of sandeels were calculated using the formula: EV (kJ) $=0.0031$ length $(\mathrm{cm})^{3.745}$ (Hislop et al. 1991). Because of the non-linearity of this equation, we calculated mean energy values by transforming quantiles from normal distributions with means given by the estimated effects and variances determined by the sum of variance components for $C_{-}$day and the residual variance corresponding to unexplained variation between fish.
Fish survey data. Additional data on length distributions of 0-group lesser sandeels present in the water column in the vicinity of the Firth of Forth were obtained from research surveys conducted by the Marine Laboratory Aberdeen on 28 June 1976, 19 June 1977, 16 and 26 June 1978, 13 June 1979, 16 and 24 June 1981, 30 May 1996, 3 July 1999 and 16 June 2000. Samples were collected during $1 \mathrm{~h}$ stepped-tows made at 3 depth strata: within $5 \mathrm{~m}$ of the surface, in midwater and along the bottom, using a pelagic trawl (PT 154) with a $6 \mathrm{~mm}$-mesh codend.

\section{RESULTS}

There was a highly significant relationship between the mean lengths of 0-group lesser sandeels obtained from the 10 fishery surveys and those collected from puffins on the same dates (Fig. 4), the mean difference being only $0.16 \pm 1.6 \mathrm{~mm}$ (paired $t$-test, $\mathrm{p}=0.92$ ). This close agreement indicated that the 2 methods were sampling the same population and thus that the longer run of data available from puffins could be used in a retrospective analysis to investigate changes in sandeel size within the Wee Bankie aggregation.

Among 0-group sandeels there was a highly significant decrease in the estimated length on 1 July over the 30-yr period (Fig. 5a). The estimated slope of $x_{-}$year in the REML model was $-0.37 \pm 0.13 \mathrm{~mm} \mathrm{yr}^{-1}$, indicating an overall reduction of $11.1 \mathrm{~mm}$ over the study period. The variance component associated with $c_{-}$year increased from 29.39 to $38.79 \mathrm{~mm}^{2}$ on exclusion of $x_{-} y e a r$ from the fixed-effect model, indicating that the trend explained some $25 \%$ of the variance between years. Because the energy value of a lesser

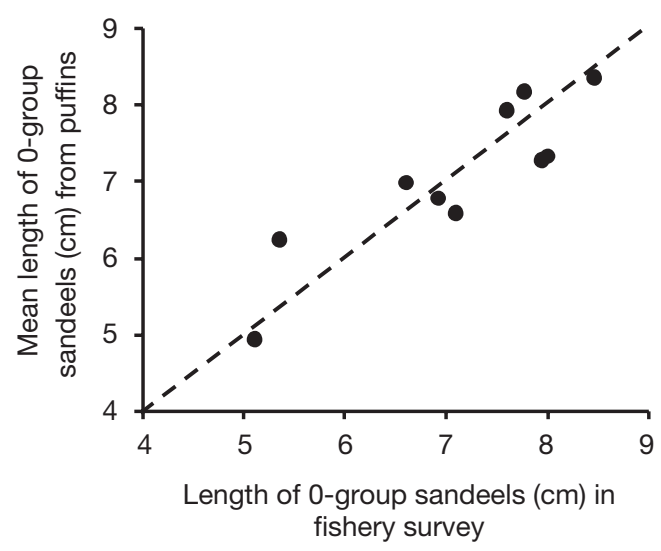

Fig. 4. Ammodytes marinus. Mean lengths of 0-group lesser sandeels collected from Atlantic puffins Fratercula arctica and by fishery surveys on 10 dates between 1976 and 2000 . Agreement between the 2 sampling methods can be assessed against dotted 1:1 line 

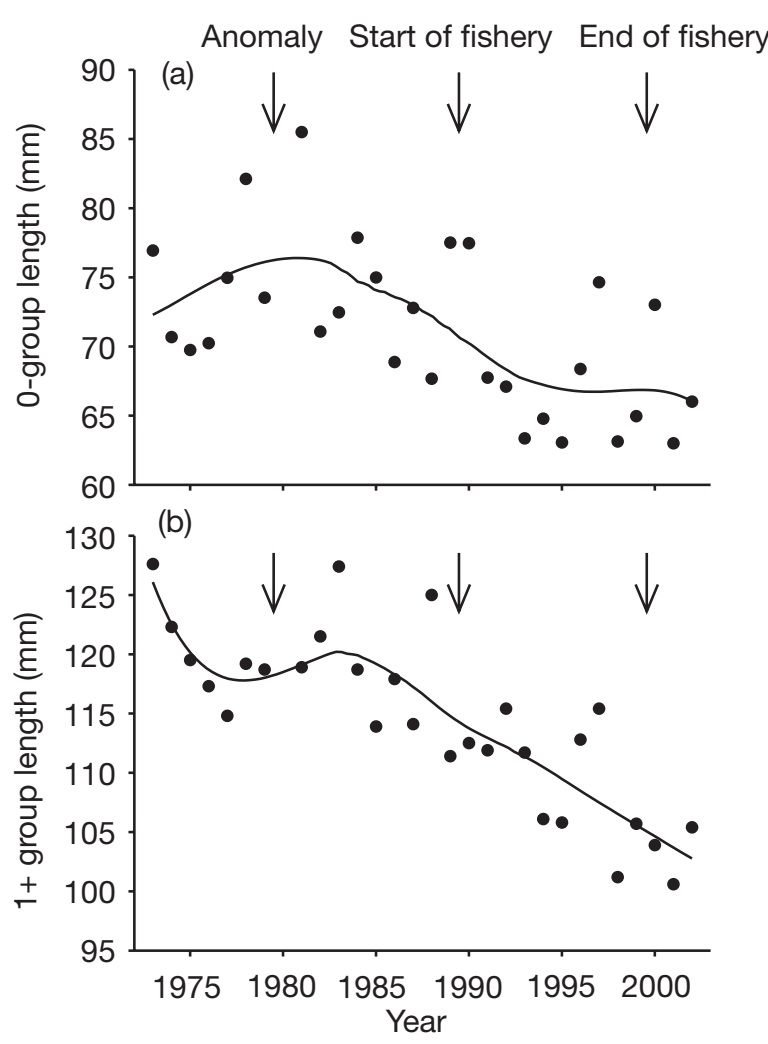

Fig. 5. Ammodytes marinus. Long-term changes in annual mean length between 1973 and 2002. (a) 0-group on 1 July; (b) older sandeels on 1 June. Trends summarised by a LOWESS smoothing function. Start and closure of industrial fishery and time of a major ocean climate anomaly in the North Sea are indicated by arrows

sandeel increases with growth by approximately the fourth power of its body length, the observed decline of $14.5 \%$ in mean length during the study period resulted in a decline in the average estimated energy value per fish of $40 \%$. The estimated regression coefficient for $x_{-}$day, representing the mean growth rate in length of 0 -group sandeels within years, was $0.409 \pm$ $0.056 \mathrm{~mm} \mathrm{~d}^{-1}$. Excluding $x_{-}$day from the fixed-effects model and the interaction between $x_{-}$day and $c_{-}$year from the random-effects model caused the variance component associated with $C_{-}$day to increase from 52.40 to $96.16 \mathrm{~mm}^{2}$, indicating that the within-year trends explained approximately $45 \%$ of the variance between days. The variance component associated with the $x_{-}$day by $c_{-}$year interaction was $0.0535 \mathrm{~mm}^{2} \mathrm{~d}^{-2}$ indicating that within-year increases in length varied between years with a standard deviation of $0.231 \mathrm{~mm} \mathrm{~d}^{-1}$. However, there was no evidence to suggest a systematic change in the rate of growth of 0 -group across years (Fig. 6). When $x_{-}$day was centred to be zero on 1 July, the estimated correlation between random terms for slope and intercept was -0.003 , suggesting that the slopes and intercepts were unrelated.

There was no statistical evidence for a departure from the model due to the Wee Bankie fishery. The estimated sizes of step-changes to length on 1 July and intra-annual growth rates were -3.5 (SE 2.8) $\mathrm{mm}(\mathrm{p}>$ 0.2 ) and -0.039 (SE 0.126) $\mathrm{mm} \mathrm{d}^{-1}(\mathrm{p}>0.7)$ respectively. The estimated changes of slope in the brokenstick models at the onset of the fishery were -0.72 (SE 0.66) $\mathrm{mm} \mathrm{yr}^{-1}(\mathrm{p}>0.3$ ) and -0.018 (SE 0.019) $\mathrm{mm}$ $\mathrm{d}^{-1} \mathrm{yr}^{-1}(\mathrm{p}>0.2)$ for length on 1 July and intra-annual growth rates respectively. Conversely, there was some weak evidence for a change-point between 1980 and 1981. The estimated sizes of step-changes to length on 1 July and intra-annual growth rates were - 5.9 (SE 3.9) $\mathrm{mm}(\mathrm{p}>0.1)$ and -0.03 (SE 0.13) $\mathrm{mm} \mathrm{d}^{-1}$ ( $\left.\mathrm{p}>0.8\right)$ respectively. The estimated changes of slope in the broken-stick models at the onset of the fishery were -1.39 (SE 0.69) $\mathrm{mm} \mathrm{yr}^{-1}(\mathrm{p}=0.05)$ and -0.002 (SE 0.025) $\mathrm{mm} \mathrm{d}^{-1} \mathrm{yr}^{-1}(\mathrm{p}>0.9)$ for length on 1 July and intraannual growth rates respectively.

For the older sandeels, a significant reduction in the length (in this case standardised to 1 June) was also apparent over the 30-yr period (Fig. 5b). The estimated slope of $x_{-}$year in the REML model, representing the net change per year on 1 June, was $-0.64 \pm 0.17 \mathrm{~mm}$ $\mathrm{yr}^{-1}$, indicating a decrease of $19.2 \mathrm{~mm}$ over the study period. As with the 0 -group, the $15.5 \%$ reduction in mean length equated to about a $40 \%$ reduction in energy value of older sandeels. We did not test formally for a fishery or an environmental effect of length-at-date in older sandeels. However, there was no qualitative evidence that the decrease in size coincided with the start of the Wee Bankie fishery, but rather the decline appeared to originate in the early 1980s.

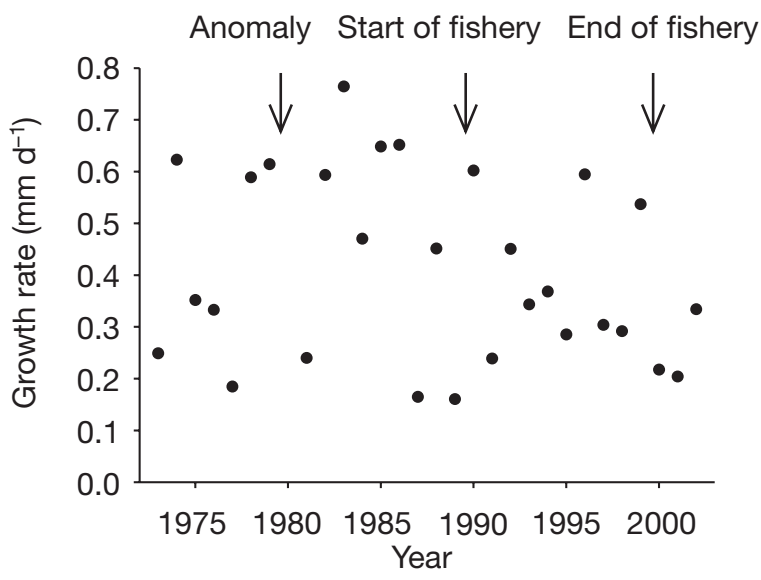

Fig. 6. Ammodytes marinus. Mean annual growth rates of 0-group from 1973-2002. Start and closure of industrial fishery and time of a major ocean climate anomaly in the North Sea are indicated by arrows 


\section{DISCUSSION}

Use of seabirds as a cost-effective way of monitoring the marine environment has received considerable attention (e.g Croxall et al. 1988, Furness \& Camphuysen 1997, Montevecchi \& Myers 1997, Tasker \& Furness 2003). However, the use of dietary samples from seabirds to monitor changes in the size composition of prey populations can potentially give biased results if birds are limited in their foraging depth range and/or show strong selection for particular sizes of prey. In this study we were able to compare the sizes of sandeels brought in by Atlantic puffins to provision their chicks with those from stepped-tows made during fishery research surveys. We found good agreement between the 2 methods and thus are confident that the more extensive data set available from the puffins provides an accurate assessment of long-term changes in the lengths of 0-group sandeels in this area.

Our results indicate that the slow growth and low weight-at-age that has recently been found among sandeels in the Wee Bankie aggregation (ICES 2003, P. J. Wright unpubl. data) is part of a long-term decline in size extending back over a 30 -yr period. In terms of assessing whether the Wee Bankie fishery or environmental factors are responsible for this decline, the findings are not consistent with the fishery being the major cause. First, the decrease was evident well before the start of the fishery in 1990, and second, changes were clearly apparent in 0-group fish and hence had occurred prior to the age at which sandeels become vulnerable to this fishery, which targets predominantly older fish (Rindorf et al. 2000). Few similar long-term data are available for other sandeel aggregations, making it difficult to assess the applicability of our results to the North Sea as a whole. Data for sandeels from Shetland in the early 1990s indicated that 0-group size varied greatly among years but, on average, fish were larger than those recorded from the Wee Bankie aggregation over the same period (Wright \& Bailey 1996, Wright et al. 1997). Pedersen et al. (1999) reported a weak, but positive, trend in the mean weight at Age 1 for sandeels caught at fishing grounds in both the central east and west North Sea between 1984 and 1997. Thus, while comparative data are limited, the available evidence suggests that the reported changes at the Wee Bankie are not reflected on a North Sea level.

On average, 0-group sandeels on 1 July 2002 were $14.5 \%$ smaller than on the same date in 1973, with comparable values for older sandeels on 1 June of $15.5 \%$. Moreover, because of the non-linear relationship between energy value and body length, these declines translate into even more substantial reductions $(40 \%)$ in terms of energy value. The observed reduction in mean length of 0 -group sandeels at a given date could be due to either changes in growth rate and/or hatch times. Although growth rate in June and July was highly variable, we found no evidence of a systematic decline during the study (Fig. 6), suggesting that slow growth prior to this period (when the sandeels are very small and puffins are not bringing fish ashore) or delayed hatching date were more likely to have been responsible for the decline. Information on the appearance of sandeel larvae in the western North Sea between 1948 and 1972 suggests that in most years the onset of hatching is in March although occasionally larvae first appear in February or April (Langham 1971, Coombs 1980). Currently nothing is known about the relative contribution of spawning time and embryonic development rate to this variation in hatch times. However, in the Shetland region the hatching period of sandeels is more extensive than the spawning period, suggesting that both spawning time and embryonic development can be important (Gauld \& Hutcheon 1990, Wright \& Bailey 1996). At present we cannot distinguish whether the observed changes in length-at-date in 0-group sandeels in the Wee Bankie aggregation stem from changes in the timing of events earlier in the season or from changes in the rates of embryonic or larval development. However, some idea of the temporal shift involved can be estimated from the mean long-term decline in length

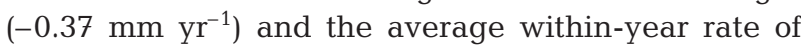
increase in length $\left(0.409 \mathrm{~mm} \mathrm{~d}^{-1}\right)$. Combining these values suggests that size at a given date has been delayed by $0.90 \mathrm{~d} \mathrm{yr}^{-1}(0.37 / 0.409)$ i.e. by about $1 \mathrm{mo}$ over a 30-yr period. Clearly these calculations need to be treated with caution, but they do nevertheless serve to illustrate the potential magnitude of the phenological change that has occurred.

The duration of embryonic development in sandeels is inversely related to sea temperature and oxygen concentration (Winslade 1971). Thus, warm winter temperatures promote early hatching and, given unlimited prey densities, high larval growth rates (Buckley et al. 1984). However, unusually early hatching can result in poor synchrony with food availability and hence a smaller size in June than for later hatched larvae (Wright \& Bailey 1996). Conversely, whilst very late-hatching larvae may grow rapidly, the short growing period means they will not reach a large size by June. Hence, the observed decrease in length at a given date could potentially arise from either very early or late hatching and both high and low sea temperatures could be expected to have had a negative effect on the 0-group size at 1 July. It is therefore interesting that the start of the decrease in sandeel length in the early 1980s coincided with a major oceanic anomaly in the North Sea 
characterised by reduced salinities and temperatures (Dickson et al. 1988, Turrell et al. 1992). This was followed by an opposite scenario in the late 1980s and early 1990s, with elevated salinities and temperatures (Edwards et al. 2002). Both these events were associated with profound changes in the biomass, community structure and phenology of plankton in the North Sea (Lindley et al. 1990, Reid et al. 1992, Edwards et al. 2002). Data on fish stocks also indicated major changes in distribution, abundance and demography during these periods (Corten \& van de Kamp 1992, Reid et al. 2001, Beaugrand et al. 2003). Oceanographic events in the late 1980s and early 1990s were also implicated in poor sandeel recruitment in Shetland, where larval dispersal and active movements of 0-group juveniles connect the relatively small spawning aggregations around Shetland with much larger aggregations around Orkney (Wright 1996, Wright \& Bailey 1996). Evidence from a larval transport model suggested that high Atlantic inflow through the Fair Isle channel in the late 1980s and early 1990s displaced larvae away from Orkney and Shetland (Proctor et al. 1998), and this was reflected in the distribution of pre-settled 0-group sandeels (Wright 1996). The sustained period of low recruitment led to the collapse of the Shetland sandeel aggregation and poor breeding success in local seabird colonies. This event illustrates the need to examine the effects of oceanographic influences on the life-history and phenology of other aggregations of sandeels in the North Sea and to assess the wider implications of any relationships for predators of sandeels.

The maturity-at-age key for lesser sandeels currently used by the ICES working group assumes $100 \%$ maturity at Age 2 and older (ICES 2003). As maturation decisions are annual events and the threshold for maturing is only a few centimetres (e.g. 9.5 to $13.5 \mathrm{~cm}$ total length for Shetland waters and the Moray Firth: Macer 1966, Gauld \& Hutcheon 1990), the observed decline in size of the older sandeels in the Wee Bankie aggregation could have led to a significant reduction in the numbers maturing by Age 2. Fecundity also scales to size, and so smaller size-at-age will be reflected in reduced fecundity at age (Macer 1966, Gauld \& Hutcheon 1990). The combined effects of an increase in age-at-maturity and lower age-specific fecundity will have tended to make the Wee Bankie aggregation more vulnerable to collapse due to recruitment overfishing leading to reduced reproductive potential and hence reduced capacity to produce recruits.

The findings also have important implications for seabirds and other natural predators, many of which depend on sandeels during their summer breeding seasons (Furness \& Tasker 2000). The decrease in length of both 0-group and older fish results in even more marked decreases in energy value and thus the quality of prey available at a given date. Such an effect may be particularly severe for species such as the common guillemot Uria aalge, which only brings back a single prey item per feeding trip for its chick, and for which maximising the energy value of items delivered is therefore critical. It is thus of interest that long-term monitoring of the prey brought in for guillemot chicks on the Isle of May has shown that the importance of older sandeels has been declining in recent years (Wilson et al. 2003). Other species, notably the blacklegged kittiwakes Rissa tridactyla and the terns Sterna spp., rely heavily on 0-group sandeels to provision their young. The long-term decline in length-at-date of this age class could therefore have an adverse effect on these species unless birds are able to adjust their time of breeding to match temporal shifts in the 0-group. Data on fecundity and diet of kittiwakes on the Isle of May and Shetland indicate that breeding success is consistently higher in years when the 0-group appear early in the diet and when the mean size of the 0-group is relatively large (Wright 1996, Lewis et al. 2001), while examination of long-term trends in phenology indicate that breeding of kittiwakes on the Isle of May has become delayed by $5.1 \mathrm{~d}$ per decade (Frederiksen et al. 2004), a shift that is consistent with that seen in the timing of 0-group sandeels.

The present study has highlighted a long term decline in length of lesser sandeels in an aggregation that is important both for natural predators (Wanless et al. 1998) and the industrial fishery (Rindorf et al. 2000). Whilst there is currently no local assessment and management of the Wee Bankie region, it is clear from this study that any future attempts to forecast stock size would need to account for long-term trends in fish size. Understanding the environmental factors leading to the declining length-at-date in Wee Bankie sandeels is clearly important for any ecosystem approach to the management of this and other sandeel aggregations. Further work is needed to investigate the causes of this decline in sandeel length and, in particular, to evaluate the roles of early growth and hatch date.

Acknowledgements. We thank the many people who have helped with fieldwork over the years, particularly S. Murray, S. Russell, T. and A. Dewdney, S. Finney, A. Leitch, C. Wernham and J. Calladine. We are grateful to L. Wilson for measuring and ageing otoliths and preparing the figures. Part of the fieldwork was carried out with funding from the Joint Nature Conservation Committee's integrated seabird monitoring programme. Scottish Natural Heritage allowed us to work on the Isle of May National Nature Reserve. P.J.W. was supported by the Scottish Executive ROAME MF 0463 contract. F. Daunt, M. Frederiksen, G. Horgan, S. Redpath, B. Turrell and 4 anonymous referees provided helpful comments on earlier versions of the paper. 


\section{LITERATURE CITED}

Beaugrand G, Brander KM, Lindley JA, Souissi S, Reid PC (2003) Plankton effect on cod recruitment in the North Sea. Nature 426:661-664

Bergstad OA, Høines AS, Jørgensen T (2002) Growth of sandeel, Ammodytes marinus, in the northern North Sea and Norwegian coastal waters. Fish Res 56:9-23

Buckley LJ, Turner SI, Halavik TA, Smigielski AS, Drew SM, Laurence GC (1984) Effects of temperature and food availability on growth, survival and RNA-DNA ratio of larval sandeel lance (Ammodytes americanus). Mar Ecol Prog Ser 15:91-97

Burger AE, Simpson M (1986) Diving depths of Atlantic puffins and common murres. Auk 103:828-830

Coombs SH (1980) Continuous plankton records: a plankton atlas of the North Atlantic and North Sea. Bull Mar Ecol $8: 229-281$

Corten A, van de Kamp G (1992) Natural changes in pelagic fish stocks of the North Sea in the 1980s. ICES Mar Sci Symp 195:402-417

Croxall JP, McCann TS, Prince PA, Rothery P (1988) Reproductive performance of seabirds and seals on South Georgia and Signy Island, South Orkney Islands 1976-1987. In: Sahrhage D (ed) Antarctic Ocean and resources variability. Springer Verlag, Berlin, p 261-285

Dickson RR, Meincke J, Malmberg SA, Lee AJ (1988) The 'great salinity anomaly' in the North Atlantic 1968-82. Prog Oceanogr 20:103-151

Edwards M, Beaugrand G, Reid PC, Rowden AA, Jones MB (2002) Ocean climate anomalies and the ecology of the North Sea. Mar Ecol Prog Ser 239:1-10

Frederiksen M, Harris MP, Daunt F, Rothery P, Wanless S (2004) Scale-dependent climate change signals drive breeding phenology of three seabird species. Glob Change Biol 10:1214-1221

Furness RW, Camphuysen CJ (1997) Seabirds as monitors of the marine environment. ICES J Mar Sci 54:726-737

Furness RW, Tasker ML (2000) Seabird-fishery interactions: quantifying the sensitivity of seabirds to reductions in sandeel abundance, and identification of key areas for sensitive seabirds in the North Sea. Mar Ecol Prog Ser 202: $253-264$

Gauld JA, Hutcheon JR (1990) Spawning and fecundity in the lesser sandeel, Ammodytes marinus Raitt, in the northwestern North Sea. J Fish Biol 36:611-613

GenStatCommittee (2002) GenStat ${ }^{\circledR}$ Release 6.1 Reference Manual Part 1: Summary. VSN International, Oxford

Greenstreet SPR (1996) Estimation of the daily consumption of food by fish in the North Sea in each quarter of the year. Scott Fish Res Rep 55

Hamer KC, Phillips RA, Wanless S, Harris MP, Wood AG (2000) Foraging ranges, diets and feeding locations of gannets Morus bassanus in the North Sea: evidence from satellite telemetry. Mar Ecol Prog Ser 200:257-264

Harris MP (1984) The puffin. T \& AD Poyser, Calton

Harris MP, Hislop JRG (1978) The food of young puffins (Fratercula arctica). J Zool 185:213-239

Harris MP, Wanless S (1986) The food of young razorbills on the Isle of May and a comparison with that of young guillemots and puffins. Ornis Scand 17:41-46

Harris MP, Wanless S (1991) The importance of the lesser sandeel Ammodytes marinus in the diet of the shag Phalacrocorax aristotelis. Ornis Scand 22:375-882

Harwood J, Croxall JP (1988) The assessment of competition between seals and commercial fisheries in the North Sea and the Antarctic. Mar Mamm Sci 4:13-33
Hislop JRG, Harris MP (1985) Recent changes in the food of young puffins Fratercula arctica in relation to fish stocks. Ibis 127:234-239

Hislop JRG, Harris MP, Smith JGM (1991) Variation in the calorific value and total energy content of the lesser sandeel (Ammodytes marinus) and other fish preyed on by seabirds. J Zool 224:501-517

ICES (1995) Report of the ICES workshop on sandeel otolith analysis: review of sandeel biology. Int Counc Explor Sea Comm Meet 1995/G:4

ICES (2003) Report of the working group on the assessment of demersal stocks in the North Sea and Skagerrak 2002. Int Counc Explor Sea Comm Meet 2003/ACFM:02

Langham NPE (1971) The distribution and abundance of larval sandeels (Ammodytidae) in Scottish waters. J Mar Biol Assoc UK 51:597-707

Lewis S, Wanless S, Wright PJ, Harris MP, Bull J, Elston DA (2001) Diet and breeding performance of black-legged kittiwakes Rissa tridactyla at a North Sea colony. Mar Ecol Prog Ser 221:277-284

Lindley JA, Rockell J, Warner AJ, Halliday NC, Hunt HG, John AWG, Jonas TD (1990) Doliolids in the German Bight in 1989: evidence for exceptional inflow into the North Sea. J Mar Biol Assoc UK 70:679-682

Macer CT (1966) Sandeels (Ammodytidae) in the southwestern North Sea; their biology and fishery. Fish Investig Ser II Mar Fish GB Minist Agric Fish Food 2 24:1-51

Montevecchi WA, Myers RA (1997) Centurial and decadal oceanographic influences on changes in Northern gannet populations and diets in the north-west Atlantic: implications for climate change. ICES J Mar Sci 54:608-614

Munk P, Wright PJ, Pihl NJ (2002) Distribution of the early larval stages of cod, plaice and lesser sandeel across haline fronts in the North Sea. Estuar Coast Shelf Sci 55: 139-149

Patterson HD, Thompson R (1971) Recovery of inter-block information when block sizes are unequal. Biometrika 58: 93-108

Pedersen SA, Lewy P, Wright P (1999) Assessments of the lesser sandeel (Ammodytes marinus) in the North Sea based on revised stock divisions. Fish Res 41:221-241

Proctor R, Wright PJ, Everitt A (1998) Modelling the transport of larval sandeels on the north west European shelf. Fish Oceanogr 7:347-354

Reay PJ (1970) Synopsis of biological data on North Atlantic sandeels of the genus Ammodytes. FAO Fish Synop 82: $1-42$

Reeves SA (1994) Seasonal and annual variation in catchability of sandeels at Shetland. Int Counc Explor Sea Comm Meet 1994/D:19

Reid PC, Surey-Gent SC, Hunt HG, Durrant AE (1992) Thalassiothrix longissima, a possible oceanic indicator species in the North Sea. ICES Mar Sci Symp 195:268-277

Reid PC, Borges MF, Svendsen E (2001) A regime shift in the North Sea circa 1988 linked to changes in the North Sea horse mackerel fishery. Fish Res 50:163-171

Rindorf A, Wanless S, Harris MP (2000) Effects of changes in sandeel availability on the reproductive output of seabirds. Mar Ecol Prog Ser 202:241-252

Tasker ML, Furness RW (2003) Seabirds as monitors of the marine environment. Int Counc Explor Sea Coop Res Rep 258

Turrell WR, Henderson EW, Slesser G, Payne R, Adams RD (1992) Seasonal changes in the circulation of the northern North Sea. Contin Shelf Res 12:257-286

Wanless S, Harris MP, Greenstreet SPR (1998) Summer sandeel consumption by seabirds breeding in the Firth of 
Forth, south-east Scotland. ICES J Mar Sci 55:1141-1151 Wilson LJ, Wanless S, Harris MP, Russell D (2003) Isle of May seabird studies in 2002. Joint Nature Conservation Committee (JNCC) Rep No 338:1-29

Winslade P (1971) Behavioural and embryological studies on the lesser sandeel Ammodytes marinus (Raitt), $\mathrm{PhD}$ thesis, University of East Anglia, Norwich

Wright PJ (1996) Is there a conflict between sandeel fisheries and seabirds? A case study at Shetland. In: Greenstreet SPR, Tasker ML (eds) Aquatic predators and their prey, Fishing News Books, Blackwell Science, Oxford, p $154-165$

Editorial responsibility: Otto Kinne (Editor),

Oldendorf/Luhe, Germany
Wright PJ, Bailey MC (1993) Biology of sandeels in the vicinity of seabird colonies at Shetland. Marine Laboratory, Aberdeen Scottish Office Agriculture and Fisheries Department, Aberdeen

Wright PJ, Bailey MC (1996) Time of hatching in Ammodytes marinus from Shetland waters and its significance to early growth and survivorship. Mar Biol 126:143-152

Wright PJ, Stagg R, McIntosh A (1997) The impact of the Braer oil spill on sandeels around Shetland. In: Davies J, Topping G (eds) Proceedings of the Royal Society of Edinburgh symposium on the Braer oil spill. The Royal Society of Edinburgh, Edinburgh, p 161-181

Submitted: October 1, 2003; Accepted: May 25, 2004

Proofs received from author(s): September 21, 2004 